\title{
Field Occurrence, Petrography and Structural Characteristics of the Basement Rocks in the Northern Part of Kushaka and Birnin Gwari Schist Belts, Northwestern Nigeria
}

\author{
Kehinde Oluyede $^{1} \quad$ Garba Ibrahim $^{1} \quad$ Umar Danbatta $^{1} \quad$ Paul Ogunleye $^{1} \quad$ Urs Klötzli $^{2}$ \\ 1.Department of Geology, Ahmadu Bello University Zaria, Nigeria \\ 2.Department of Lithospheric Research, University of Vienna, Austria
}

\begin{abstract}
Field, studies and geological mapping on a scale of 1:50000 were carried out to determine the lithologic framework and structural features of the Basement Complex rocks in northern parts of the Kushaka and Birnin Gwari schist belts (Kushaka Sheet 122). The area is underlain predominantly by five main rock types mainly (i) MigmatiteGneiss-Quartzite suite comprising dioritic, granodioritic and granitic gneisses with fissile and ferruginous quartzites and banded iron formations (BIF); (ii) Kushaka graphite and sulphur bearing biotite and muscovite quartz schist inter-banded in places with iron formations; (iii) Birnin Gwari biotite-staurolite quartz schist; iv) the Kushaka Gneiss Complex composed of basalts (which is being reported for the first time), staurolite and muscovite gneisses and banded iron formations (BIF), and (v) syn-tectonic and late-orogenic biotite-hornblende syenite (BHS) and biotite-hornblende granite (BHG) in the Kushaka schist belt and biotite muscovite granite (BMG) in the Birnin Gwari schist belt area. Petrographic studies have revealed that essential minerals are quartz, K-feldspars (orthoclase, microcline), plagioclase, pyroxene, epidote, hornblende, biotite and muscovite while the accessory minerals are titanite, zircon, apatite, iron oxide (magnetite and hematite). With pyroxenes occurring in the dioritic and granodioritic rocks, metamorphism may have locally reached grannulite facies. Imprints of Pan-African thermo-tectonic events have shown observable migmatization as the first thermo-tectonic event resulting in plastic deformation $\mathrm{D}_{1}$ and regional $\mathrm{S}_{1}$ foliation, demostrated by presence of tight isoclinals fold, compositional banding and $\mathrm{N}-\mathrm{S}$ preferred orientation of mafic minerals. The $\mathrm{D}_{2}$ deformation is co-axial with $\mathrm{D}_{1}$ and resulted in the formation of decimeter sized $F_{2}$ isoclinal folds, $B_{2}$ boudins and eye ball structures that are parallel to $S_{1}$ plane schistocity. Strike-slip faults with dextral sense of movements were mapped in a number of places. $\mathrm{D}_{3}$ deformation is concentrated in the Kushaka Gneiss Complex with near circular deep fractures south of the Kalangai fault. Here granitization and fragmentation of proto-mylonitic staurolite resulted in brittle deformation and $\mathrm{F}_{3}$ open fold that refolded or transposed the earlier tight isoclinal $\mathrm{F}_{2}$ folds. The $\mathrm{D}_{4}$ deformation resulted in N-S and NW-SE quartz veins and pegmatite dykes which serve as channels for epigenetic gold-sulphide and rare metal bearing ore fluids. Keywords: Basement Complex, Pan-African, metamorphism, deformation, Kushaka, Birnin Gwari, Nigeria
\end{abstract} DOI: $10.7176 / \mathrm{JNSR} / 12-12-02$

Publication date:June $30^{\text {th }} 2021$

\section{Introduction}

The Nigerian Basement Complex is part of the Benin-Nigeria shield and lies within the Pan-African mobile belt to the east of West African craton and northwest of Congo craton. It is divided into two provinces (east and west) separated by latitude $8^{0} \mathrm{E}$ marked by a major lineament on the Landsat image (Ananaba and Ajakaiye, 1987). The eastern province comprises mainly a migmatite-gneiss complex intruded by larger volumes of Pan-African granites and the Mesozoic ring complexes of North-Central Nigeria. The western province of the Nigeria Basement Complex is characterized by narrow and sediment dominated, N-S trending, low-grade schist belts separated from each other by migmatite-gneiss complexes, intruded by Pan-African granitic plutons (Ajibade et. al., 1987; Woakes et al., 1987; Onyeagocha and Ekwueme 1990) (Fig 1). The ages of the protolith are still unclear in these provinces.

The Nigerian basement complex consists of three major rock units: (1) the Migmatite Gneiss Quartzite Complex (MGQC) dated from Archean to Early Proterozoic (2700-2000 Ma), comprising a heterogeneous assemblage of predominantly amphibolite-facies migmatites, orthogneisses, paragneisses, and minor-basic to ultrabasic rocks; (2) the N-S and NE-SW Schist Belts, believed to overlie the MGQC and consisting mainly of psammitic to pelitic metasediments with interlayered granitic gneisses and rare amphibolites, interpreted as metavolcanics; and (3) Late Proterozoic to Early Phanerozoic (750-450Ma) Older Granites, intruding both 1 and 2 and composed of tonalitic to granitic plutons and charnockites, strongly foliated to almost unfoliated, and considered to have been emplaced during the Pan-African orogeny (Rasuss,1957; McCurry, 1976; Fitches, et al.1985; Rahaman 1976; 1988; Olanrewaju, 1988; Turner 1983; Oyinloye and Ojo, 1988; Tubosun et al. 1984).

Structural trends as observed in the basement complex are the results of orientation and magmatic induced veins and pegmatite dykes (Ajibade et al., 1984; Rahaman, 1988). The two phases of deformation are both ductile and brittle; the former being responsible for formation of planar structures (foliation) and the latter resulting in 
jointing and fractures, many of which are filled with quartzo-felspathic veins, dolerite dykes, pegmatitc and aplite veins and dykes. The principal fracture directions in the basement complex of Nigeria are N-S, NNE-SSW, NNWSSE and NW-SE, and to a lesser extent E-W where the N-S fractures are marked by considerable shearing and brecciations, with probably more than one period of mineralization. The NE-SW and NW-SE conjugate sets are mostly strike slip faults with the north eastern set characterized by dextral sense of movements (Garba, 2002; Okunlola and Okoroafor, 2009). Mineralizations such as iron-ore, gold quartz vein carrying galena and pyrite are generally confined within the N-S to NNE-SSW brittle structures (Goki et al., 2010; Kolawole et al., 2017).

The schist belts are best developed and exposed in a zone, about $300 \mathrm{~km}$ wide, characterised by of the presence of low to medium grade metasedimentary and metavolcanic rocks and NNE-SSW and N-S structural trends in the northwest part of the country. In addition to the low to medium grade metasedimentary rocks, schist occurs as slightly migmatised to unmigmatised paraschists and metaigneous rocks in the southwest and predominantly as series of synformal troughs and strike ridges. (Rahaman, 1976; Danbatta, 2008b; Ekwueme, 1985) (Fig. 2).

Detailed studies have been made on the Kushaka and Birnin Gwari schist belts in terms of structures and mineralization (Grant, 1978; Garba, 2000; 2002) due to the fact that they are known to host important economic mineral deposits, and constitute a major lithostratigraphic unit necessary for unravelling the geochemical and geodynamic evolution of the basement complex (Ekwueme, 2003; Danbatta, 2008b; Ekwueme and Ephraim, 2005). Although, the study area have benefited from interest by mineral prospectors, geochemists and economic geologist especially on structural and geochemical controls of mineralization, relatively little information has emerged concerning mineralogy and relations of the migmatite gneiss quartzite complex to the schist belts and the granitoids. This paper therefore examines the field data obtained from geologic mapping on a scale of 1: 50,000 with a view to determine the field lithologic disposition, petrography and structural features of the rock outcrops in the study area and to present a preliminary petrogenetic and geotectonic history of the study area. This will contribute to our understanding of the tectonic evolution of the basement complex in the region.

\section{Materials and Methods}

A detailed and systematic field mapping of the study area covered by Kushaka Sheet 122 topographic map was carried out on a scale of 1:50,000 to delineate the major and minor rock boundaries. Field relations of the rock units of the area were determined and documented field measurements of attitude of structures carried out using a Bruton compass clinometer. In the field, joints, fractures and faults, lineations and foliations were the main structural elements recorded. All the readings were documented and data plotted as Rose diagrams using the GeoRose 0.5.1 software. Thirty eight representative samples of granitoids were carefully selected for petrographic studies in the following areas: (i) Kushaka schist belt (8), (ii) Birnin Gwari schist belt (8), (iii) Migmatite-GneissQuartzite Basement Complex (15), and (iv) Kushaka Gneiss Complex (5). Others are Kushaka metasediments (2), Birnin Gwari meta-sediments (3), BIF (1) and amphibolites (1). Thin sections of these rocks were prepared and petrographic studies were carried out using research microscope at the Department of Geology, Ahmadu Bello University, Zaria. Average modal composition of the rocks was estimated from thin section studies using the JMicrovision software of Nicholas Roduit version 1.2.7 (Table 2).

\section{Results and Discussion}

\subsection{Field Occurrences and Petrography of Rock Types}

The geological map of the study area on a scale of 1:50,000 was produced from geologic data obtained during field geologic mapping (Fig. 3). The rock units of this area are classified into five main lithologies: (i) MigmatiteGneiss-Quartzite suite composed of dioritic, granodioritic, granitic and granitic gneisses with fissile and ferruginous quartzites and banded iron formations (BIF); (ii) Kushaka Gneiss Complex which consists of extrusive basalts (being reported for the first time in Kushaka schist belt), staurolite and muscovite gneiss and banded iron formation (BIF), (iii) Kushaka graphite and sulphur bearing biotite and muscovite quartz schist inter-banded in places with iron formations; iv) Birnin Gwari biotite-staurolite quartz schist; all of which have suffered polyphase deformation and have been intruded in places by Pan-African granitoids and (v) syn- to late- orogenic biotitehornblende syenite (BHS) and biotite-hornblende granite (BHG) in the Kushaka schist belt, and biotite muscovite granite (BMG) in the Birnin Gwari schist belt.

\subsubsection{Migmatite-Gneiss-Quartzite Basement Complex}

\subsubsection{Field Occurrence}

This Complex consists of migmatites and granitic gneisses (composed of dioritic, tonalitic, granodioritic, and granitic gneisses), relics of fissile and ferruginous quartzites and older metasediments, as xenoliths in the migmatites. Early Migmatites were observed as weathered xenoliths in the migmatites in the Rafin Taba area. Ajibade et al., (2008) described the Migmatite-Gneiss-Quartzite Complex as agmatitic and stromalitic migmatites, formed by anatexis in medium to high grade terrain in the adjacent Kusheriki sheet in which parts of Kushaka and Birnin Gwari schists lies (Fig. 3).

The Older Quartzite consists of greyish white fissile and reddish brown ferruginous quartzite. This greyish 
white and fissile facie occurs in Nasarawa Kwona as poorly exposed on low lying ridges and are aligned in N-S foliation direction (Fig. 4). The ferruginous quartzite occurs as Iron-formation interbedded with quartzite stratiform with typically finely banded structure, and is well exposed in Maganda area (Fig. 4). In the adjourning Kusheriki schist belt, south west of the study area, they are interlayered with phyllites. Migmatite gneisses occur as highly jointed and foliated high and low level rocks in which plastic deformation, mainly meso and microscopic fold structures and N - S schistocity are well preserved. They are also characterized by alternating dark bands of biotite and other dark $(2-6 \mathrm{~cm})$ and light quartzo-fedspathic minerals, referred to as Pan-African migmatite.

Migmatitic Gneiss occurs as thick bands of felsic and mafic minerals. It is easily distinguished from the migmatites with its less pervasive $\mathrm{N}-\mathrm{S}$ foliation, thick bands of paleosome and leucosome with granitic injections. The leucosome is granitic, porphyritic and discordant rock in which feldspar porphyry and dark biotite minerals are aligned in E-W direction against the general N-S foliation trend. The migmattic gneiss also occurs as dykes in which minor dextral movement in the dioritic leucosome has been recorded (Fig. 4).

Granite gneiss is a high and low levels, weakly foliated fine grained, grayish to pink and reddish brown equigrannular rocks. Although the rock is similar to the migmatite gneiss with its weak N-S trending foliation, it differs from this rock as a result of thick bands of paleosome and leucosome injections. The granite gneiss is well-exposed in Kampani Doka area where it is being quarried for constructional purpose (Fig. 4).

3.1.1.2 Petrography

Migmatite gneiss comprises thin and thick bands of paleosome composed of diorite, tonalite and granodiorite and leucosome made up of granite.

i) Diorite: This rock outcrops as a hill approximately $569 \mathrm{~m}$ high along the Birnin Gwari - Kaduna road. It is characterized by thick alternating dark (paleosome) and light (leucosome) bands, both of which vary from 0.5 to $15 \mathrm{~m}$, and are aligned in the N-S regional foliation direction. The leucosome occur as cross cutting dyke with dextral displacement (Fig. 5). Microscopically, the leucosome component consists of quartz (30\%), K-feldspar $(40 \%)$, plagioclase $(10 \%)$ and mafic components as biotite $(10 \%)$ and iron-oxide $(5 \%)$, with accessory minerals as apatite and magnetite. K-feldspars are tabular perthite and microcline with zoned inclusions of dense clay minerals. Plagioclase is also tabular and zoned in places. Quartz occurs as hypidiomorphic four to six-sided crystals at $120^{\circ}$ junction (Fig. 5) (Table 1). Accessory minerals are apatite and magnetite.

ii) Granodiorite: Granodioritic rocks consisting of thick bands of paleosome and leucosome occurs as a hill rising up to $538 \mathrm{~m}$ in Ungwan Madaki, Gwaska and Kwona Mutua area. It is a fine to medium grained rock, composed of 3-30m thick bands of felsic and mafic minerals, aligned in the N-S regional foliation direction (Fig. 5). Under the microscope the rock is seen to be composed essentially of augite (45\%), hornblende (15\%) and biotite (5\%) and iron-oxide (5\%) set in groundmass of quartz (20\%) and feldspars (10\%). Elongate, needle-like crystals of augite are mainly aligned in sub-parallel fashion although a few crystals have different crystallographic orientation. Accessory minerals are apatite, magnetite and iron-oxides (Fig. 5).

iii) Tonalite exposed along River Rafin Magami, and found as boulders and whale backs which are traceable westward for few kilometers from the bridge across the Birnin Gwari - Funtua road, north of Sabo-Layi village (Fig. 6). It is a fine to medium grained rock, grey in colour and weakly foliated tonalitic and granodioritic in composition. Under the microscope, it is observed to consist of orthoclase (5\%), plagioclase (60\%), quartz (20\%), biotite $(10 \%)$, pyroxene $(5 \%)$ with accessory iron-oxide (hematite and magnetite) and apatite. The plagioclase $\left(\mathrm{An}_{15-20}\right)$ exhibits simple polysynthetic twinning.

iv) Granite (leucosome) is coarse grained to porphyritic rock which occurs as injection in the granodiorite and paleosome in areas around Ungwan Madaki and Gwaska. Under the microscope it is found to be composed of quartz $(40 \%)$ and $\mathrm{K}$-feldspar $(40 \%)$, with biotite $(15 \%)$ as ferromagnesian mineral. Quartz occurs as euhedral to subhedral medium sized crystals in between the feldspars and is characterized by mykeritic intergrowth with orthoclase. K-feldspar consists of orthoclase (perthitic and micro-perthitic) and microcline with cross hatch twinning (Fig. 6D). The feldspars also contain dense mass of clay and mica minerals as alteration products; additionally, there is also an overgrowth of K-feldspar at the edges of the plagioclase on perthite and microcline (Fig. 5D and 6D). Anhedral crystals of biotite are scattered in the matrix and along cracks in the feldspars and as inclusions in orthoclase (Fig. 5F). Accessory minerals include zircon, apatite and magnetite. This may have been the earliest component of the Older Granites in this area as earlier reported by Ajibade et al. (2008) or gneiss and migmatite considered to be related to the Older Granite plutonism and subsequently referred to as Pan-African migmatites by Truswell and Cope (1963).

v) Granite Gneiss: Occurs as prominent outcrops (about $520 \mathrm{~m}$ high) which is being quarried for constructional material in Kampani Doka area and as low lying whale back exposures along river channels in Kugu area. It is fine grained, weakly foliated equigrannular pink to reddish and greyish brown rock, (Fig. 4). Under the microscope, the reddish brown rock is seen to be composed mainly of quartz (30\%), orthoclase $(25 \%)$ muscovite $(25 \%)$, ironoxide $(10 \%)$ and biotite $(5 \%)$. Accessory minerals include zircon, apatite, titanite and magnetite.

\subsubsection{Kushaka Gneiss Complex}

The Kushaka Gneiss Complex consists of low-lying sub-circular bodies of felsic and mafic rocks in south-west of 
the Kalangai transcurrent fault where it truncated the Kushaka metasediments. The rocks include basalt, granitoids rocks of granodioritic composition and granite gneiss. At the edge of the Kalangai transcurrent fault, the subcircular bodies rises up to $500 \mathrm{~m}$ above the surrounding area and generally dip at angle of $20^{\circ}$ to $60^{\circ} \mathrm{E}$ and SE. The basalt outcrops in the central part around Marinai and Kabugu as a dark and dense, fine grained massive volcanic rock, granular in texture, highly fractured with brittle deformation and block jointing. Under the microscope, the basalt is seen to be composed essentially of pyroxene $(60 \%)$, ranging from anhedral to subhedral glomerocryst to small prismatic crystals and showing preferred alignment of minerals. Olivine is about (10\%) in the basaltic rock and occurs as subhedral phenocrysts. It is pale brown in colour under plain polars. Quartz (20\%) and plagioclase $(10 \%)$ form part of the groundmass. Accessory minerals are titanite, zircon, apatite and garnet (Fig. 7) (Table 1).

The high level granite gneiss is characterized by minor folding $\left(F_{3}\right)$ transposing the $F_{2}$ folds with dextral displacement (Fig. 12). The western part of the granite-gneiss intrusion consists of light-coloured staurolite and muscovite gneiss with bands of dark coloured minerals in Gwagwaulu area. This phase of the rock is closely associated with banded iron formations (BIFs) and pegmatites (Fig. 3).

\subsubsection{Kushaka Quartz Biotite-Muscovite Schist}

The Kushaka metasediment comprises Fe-rich biotite, muscovite quartz schist interbedded with banded iron formations (BIFs). Two varieties are recognized in the field. (i) Fine-grained grey to silvery grey type recorded in the river channels in Kugu area; (ii) The yellowish to grayish type graphite and sulphur bearing, with iron-oxide minerals which occurs in Sabo-Layi (Fig. 8). Graphite is silvery grey to black in colour with greasy feel and smudges the hand when touched. Yhis mineral has been transformed or altered to magnetite and haematite as observed under the microscope. The Kushaka metasediments is interbedded with BIFs in Kugu and ferruginous quartzite in Maganda area, and it is characterized by microfolds, crenulation cleavages, nearly vertical dips and shows a well-defined schistocity.

\subsubsection{Birnin Gwari Quartz Biotite-Staurolite Schist}

The staurolite-biotite quartz schist of the Birnin Gwari schist belt is a whale back $\mathrm{N}-\mathrm{S}$ trending Younger metasedimentary rock composed of clastic components of quartz, schist, volcanic and quartzo-feldspathic rocks. Three units of this rock can be observed in the field namely: i) The bluish to light grey, fine to medium-grained clastic rock with flow structure. The clast (mixture of quartz, schist, volcanic and quartzo-feldspathic components) range from less than $2 \mathrm{~mm}$ to $5 \mathrm{~cm}$ and make up to $25-40 \%$ of the constituent of the rock showing angular to rounded and flattened, and are poorly sorted with range of particle sizes from sand to cobbles; ii)Dark grey finegrained rock in which the precursory sedimentary structures ripple marks, cross bedding and cross lamination are preserved and (iii) Dark, fine-grained rock with granular texture. This rock is characterized by lack of clastic materials and precursory sedimentary structures. It is found close to the Mando granite pluton (Fig. 8).

\subsubsection{Banded Iron formation}

The banded iron formation occurs as series of $\mathrm{N}-\mathrm{S}$ trending ridges and isolated hills (with elevation of $\geq 600 \mathrm{~m}$ ) in Sabo-Layi and Galadimawa area. The banded iron-formation is also interbedded with quartzite which stands out along the ridges in Maganda towards Akachi area. Ferruginous quartzites interlayered with phyllites have been observed by previous workers in the Kusheriki, south west of the study area. BIF is also interbanded with quartz schist in Kugu area where the iron-formations preserved the metasediment, making it more resistant (Fig. 3).

\subsubsection{Amphibolite}

The amphibolites occur in low lying outcrop in Kungwi area. Some of the dykes are over $1 \mathrm{~km}$ in length and $>6 \mathrm{~m}$ in width and trending $\mathrm{N} 160^{\circ}$ direction. It is a mediun grained dark coloured rock with acicular quartz occurring as bands $(1-2 \mathrm{~mm})$, trending in the regional $\mathrm{N}-\mathrm{S}$ foliation direction.

\subsubsection{Kushaka Granite}

The granite plutons intruded the Kushaka metasediments and are found in Maganda, Nasarawa- Kwona, Koriga, Manini, Udawa, Sabon-Kushaka and Kugu. They comprise biotite and hornblende-bearing syenite, biotite bearing granite and granodiorite. These intrusions form N-S trending oval and elongated bodies or whaleback with moderate to high relief on either side of the transcurrent Kalangai fault. The granite plutons occupy the intervening area/region of the basement migmatite gneisses and metasediments of the Kushaka and Birnin Gwari schist belts (Fig. 3). Megascopically, the granites range from light to dark grey, grayish yellow, grayish brown to light (iron) red in colour. They also occur as porphyritic, coarse porphyritic and medium grained, and are generally devoid of pervasive foliation, but intense deformation responsible for S1 foliation has caused some varieties to develop slight banding, with the dark minerals forming mafic enclaves.

Syenite: The syenite is a medium- to coarse-grained rock with hypidiomorphic texture and mafic enclaves. It is composed of potash feldspars $(35 \%)$, quartz $(20 \%)$, hornblende $(20 \%)$, biotite $(10 \%)$, plagioclase $(5 \%)$ and ironoxide (5\%). Parallel to sub-parallel alignment of the crystals of hornblende and biotite define the foliation direction (Fig. 9) (Table 1). Zircon, magnetite, apatite and iron oxides are the main accessory minerals.

Granite: This is a coarse-grained, grey-coloured rock with outcrop slightly elongated and $615 \mathrm{~m}$ elevation. Megascopically, it consists of grey coloured feldspar and quartz, contrasted by dark colour biotite and shining and flaky muscovite. This is a coarse hypidiomorphic rock in which the proportion of felsic minerals constitutes more 
than $60 \%$ with almost equal amounts of K-feldspar and plagioclase. The main consistuent minerals are quartz $(30 \%)$, K-feldspar (30\%), plagioclase (30\%) and biotite (10\%). Accessory minerals are muscovite, haematite and magnetite (Fig. 9).

\subsubsection{Birnin Gwari Granite}

Granite outcrops are found on the fringes of the Birnin Gwari metasediments. It is coarse porphyritic to medium grained granite which is composed of pinkish to milky feldspars, silvery muscovite flakes, and black to brownish biotite. The slightly weathered muscovite shows brownish green colour. Under the microscope, quartz (30\%) occurs as subhedral phenocryst, orthoclase $(25 \%)$ and microcline $(25 \%)$ are euhedral crystals, closely interlocked with plagioclase (5\%), and with each other (Fig. 9) (Table 1). K-feldspar occurs as subhedral phenocryst of orthoclase and micro-perthite and as subhedral to euhedral medium-grained crystals with microcline and biotite. Biotite and muscovite are fibrous and needle-like in shape, squeezed together and align in the regional foliation direction. Accessory minerals include magnetite and apatite.

\subsection{Deformation and Structural Patterns}

Field mapping have revealed two large scale contrasting structural styles: i) the N-S trending simple linear style in Birnin Gwari schist and ii) the complex N-S, NNE-SSW and NW-SE trending structural style in the migmatite gneiss and Kushaka schist and NW-SE trending structural style in the Kushaka Gneiss Complex.

The orientation of the ductile structures as determined from the strike azimuth frequency data of the structures (Table 2) are:

NNE/NE (75\%); E - W (6\%); NNW/NW (19\%)

The orientation of the brittle structures (joints/fractures and quartz veins) are as follow:

NNE/NE (43\%); E - W (12.5\%) NNW - NW (36.5\%).

The ductile structures trend in the NNE-SSW and NE-SW direction while the brittle structures trend in the NNWSSE; NW-SE and E-W direction, the E-W is predominant in the granitoids. The rose diagram plot shows that the data plot mostly in the NNE-SSW and NE-SW directions (Fig. 10). This agrees with the composite lineament aeromagnetic, Landsat and DEM maps of the study area (Fig. 5) and conforms to the strike of regional foliation trend. Abubakar (2012) combined lineaments deduced from 3D total magnetic intensity field raster image, Landsat $\mathrm{ETM}+$ and digital elevation model (DEM) to produce composite lineament map of aeromagnetic, Landsat and DEM with newly interpreted lineament which shows NE-SW and NW-SE as the major structural trend in the study area. The rose plot when compared with the aeromagnetic, Landsat and DEM lineament map shows its alignment with majority of the linear structures and similarity of field data with aerial view (Fig. 11). Four deformational episodes $\left(D_{1}-D_{4}\right)$ have led to the generation of three major foliation trends namely: near vertical N-S, NNE-SSW and NE-SW earlier documented by Grant (1978) were recorded. The planar (foliation) surfaces were observed mainly in the migmatite-gneiss-quartzite Basement Complex, Kushaka and Birnin Gwari metasedimentary rocks while joints and fractures cut across all lithologies in the area.

\subsection{1 $D_{1}$ Phase of Deformation and Structures}

The $\mathrm{E}-\mathrm{W}$ compressional stress / deformation has resulted in the regional $\mathrm{N}-\mathrm{S}$ foliation trend manifesting as synform and antiform as revealed by structural trend lines. The $\mathrm{D}_{1}$ deformation is observed in migmatite and gneisses, rocks of Birnin Gwari and Kushaka schist belts, and is associated with $\mathrm{S}_{1}$ foliation. In migmatites and gneisses, the $\mathrm{S}_{1}$ foliation is outlined by compositional banding and by preferred orientation of the dark minerals and quartzo-feldsphatic layers (Fig. 12). The $\mathrm{D}_{1}$ deformation in the Kushaka schist within the migmatites and gneissic envelope shows $\mathrm{N}-\mathrm{S}$ foliation trend and is also responsible for the observed regional $\mathrm{N}-\mathrm{S}$ alignment of the Banded Iron Formation (BIF) and its associated ferruginous quartzite earlier described by Grant, (1978) as continuous interbanded Banded Iron and Kushaka quartz schist outcrop extending for about $25 \mathrm{~km}$, observed in Maganda outcrop in the north. $\mathrm{D}_{1}$ deformation in Birnin Gwari staurolite and quartz schist is characterized by wellpreserved ripple marks, cross bedding, phenocrysts of vesicles and flow structure in $\mathrm{N}-\mathrm{S}$ regional foliation trend (Fig. 8). A planar orientation is also observed in the granites where the porphyritic varieties show aligned feldspar porphyries parallel to regional foliation direction. The $F_{1}$ fold even though occurs at megascopic scale was not observed in the field, but photo geological trend did show the major antiform and synform in the gneisses and migmatites and Kushaka metasediment respectively; with axes oriented in $\mathrm{N}-\mathrm{S}$ direction. The $\mathrm{F}_{1}$ megascopic folds have $S_{1}$ as axial plane schistocity. All axial trends are parallel and vary between $160^{\circ}$ and $180^{\circ}$ (Fig. 10).

\subsection{2 $\mathrm{D}_{2}$ Phase of Deformation and Structures}

The $\mathrm{D}_{2}$ deformation has been recorded both in the metasediments and metamorphic rock units. It is characterized by heterogeneous deformation affecting the $\mathrm{N}-\mathrm{S}$ regional orientation of the $\mathrm{D}_{1}$ fabric. The $\mathrm{D}_{2}$ deformation led to development of minor structures in the metasediments, migmatites and gneissic rocks. The most widely developed are the $\mathrm{F}_{2}$ and $\mathrm{F}_{3}$ folds.

Clearly visible in the migmatites and gneissic rocks are the $\mathrm{F}_{2}$ isoclinal folds, $\mathrm{B}_{2}$ boudins and eye ball structure. The $F_{2}$ fold occurs only as decimeter sized isoclinal fold with $S_{1}$ parallel to the axial plane schistocity and in places with crestal thickening (Fig. 12). These structures are not observed in the granite gneisses, implying that the 
gneisses may post-date the $D_{2}$ phase. $F_{2}$ folds over-printed the $D_{1}$ structures and $S_{1}$ schistocity is folded by the $F_{2}$ folds. The $\mathrm{D}_{2}$ folds represent the main folding phase and are clearly visible at megascopic scale. These $\mathrm{F}_{2}$ folds also have various morphological aspects: (i) upright folds; (ii) disharmonic folds (iii) simple fold. The wavelength of many $F_{2}$ folds varies from $15-30 \mathrm{~cm}$ with the amplitude of $10-20 \mathrm{~cm}$. Some of the $F_{2}$ small scale folds have either asymmetric $\mathrm{S}$ or $\mathrm{Z}$ shape and symmetric $\mathrm{M}$ or W shape depending on their location and relation to $\mathrm{F}_{3}$ folds. The $\mathrm{D}_{2}$ deformation is also marked by sub-vertical fractures resulting in leucosome injection and strike slip fault all which are oriented in the regional foliation direction (Fig. 4). This could be the late phase of $\mathrm{D}_{2}$ deformation, as observed from porphyritic granite injection in the migmatite gneiss rock in Gwaska area.

\subsection{3 $D_{3}$ Phase of Deformation and Structures}

The $\mathrm{D}_{3}$ deformation is preserved in the Kushaka Gneiss Complex, south of Kalangai transcurrent fault and the Kushaka ferruginous quartzite as microfolds and crenulation cleavages. It is a phase of superimposed folding, where the structures associated with this phase of deformation are the result of the transposition and re-orientation of the $\mathrm{D}_{2}$ structures. The $\mathrm{F}_{3}$ folds typically form interference patterns that are associated with the development of later minor folds across the earlier structures. The fold axes of $F_{3}$ folds are parallel to $F_{2}$ fold axes, thus $F_{3}$ open fold orientation is probably coaxial with the earlier tight and isoclinals $\mathrm{F}_{2}$ folds (Fig. 12). In the Kushaka Complex, the $\mathrm{D}_{3}$ phase of deformation and structures are marked by $\mathrm{F}_{3}$ open folds and the fold axes are perpendicular to the foliation direction. The $\mathrm{S}_{3}$ schistocity overprinted the pre-existing $\mathrm{S}_{1}$ schistocity in form of stretching lineation parallel to the $\mathrm{N}-\mathrm{S}$ axial plane but with moderate dip $35^{0}-40^{\circ} \mathrm{E}$. The $\mathrm{L}_{3}$ lineation associated with $\mathrm{S}_{3}$ is subparallel to $\mathrm{F}_{3}$ fold axes. The shearing movement associated with the $\mathrm{D}_{3}$ phase of deformation is dextral and trend $180^{\circ}$ on the average. This is clearly visible in Kabugu and Marinai where $F_{3}$ fold limbs are dissected by $C_{3}$ shear plane (Fig. 12).

\subsection{4 $\mathrm{D}_{4}$ Phase of Deformation and Structures}

The $\mathrm{D}_{4}$ deformation is marked by locally developed strain-slip cleavage observed in the migmatites and gneisses. It cross-cut the Kushaka and Birnin Gwari schists, the banded iron formations and part of the granite gneiss of the Kushaka Complex, and probably reactivated the Kalangai fault. This deformation is also responsible for the squeezing of residual granitic magma into late sub-vertical fractures and joints, felsic pegmatite intrusion and strike slip faults (Fig. 12). Grant (1978) recognized 4 generation of minor folds $\left(F_{1}-F_{3}\right)$ followed by locally developed strain - slip cleavage cutting across associated $\mathrm{F}_{3}$ folds south of Kalangai fault.

\subsubsection{Other Structures:}

These are minor sedimentary structures like well-preserved ripple marks, cross bedding, lineation, phenocrysts, vesicles and flow structure in the Birnin Gwari meta-volcano-sedimentary rock. It is difficult to ascribe these minor structures to a particular deformation episode but probably $\mathrm{D}_{1}$ and $\mathrm{D}_{2}$.

\subsection{Conclusion}

Field mapping and analysis of petrographic and structural data on the rocks of the study area show that the main rock types are (i) a Migmatite-Gneiss-Quartzite suite comprising dioritic, granodioritic and granitic gneisses with fissile and ferruginous quartzites and banded iron formations (BIF); (ii) the Kushaka graphite and sulphur bearing biotite and muscovite quartz schists inter-banded in places with iron formations; (iii) the Birnin Gwari biotitestaurolite quartz schist; iv) the Kushaka Gneiss Complex composed of basalts (which is being reported for the first time), staurolite and muscovite gneiss and banded iron formations (BIF) and (v) syn- tectonic and late- orogenic biotite-hornblende syenite (BHS) and biotite-hornblende granite (BHG) in the Kushaka schist belt and biotite muscovite granite (BMG) in the Birnin Gwari schist belt area. The Kushaka and Birnin Gwari granites are assumed to be the youngest rock which intruded the Migmatite-Gneiss-Quartzite Basement Complex and Kushaka and Birnin Gwari schist belts.

Petrographic studies have revealed that the essential minerals are quartz, K-feldspars (orthoclase, microcline), plagioclase, pyroxene, hornblende, biotite, muscovite while the accessory minerals are titanite, zircon and iron oxide (magnetite and hematite). Migmatite-Gneiss-Quartzite Basement Complex rock contains pyroxene especially the dioritic and granodioritic rocks, which lend credence to its formation by anatexis; where metamorphism may have locally attained grannulite facie. Ajibade et al., (2008) have reported agmatitic and stromalitic migmatite, formed by anatexis in medium to high grade terrain in the adjacent Kusheriki sheet which hosts parts of Kushaka and Birnin Gwari schists. Graphic texture in orthoclase (perthitic and micro-perthitic) and microcline with cross hatch twinning in the granite leucosome is typical of magmatic intergrowths, however, overgrowth of secondary K-feldspar (light gray) on end and sides of albite-twinned plagioclase crystal (dark gray), this may have resulted from metasomatic processes. This is an indication that granite injections that had undergone matasomatism.

The rocks of the area recorded majorly N-S NNE-SSW and NE-SW planar structures and minor NW and EW structural trend. The N-S, NNE-SSW and NE-SW represent ductile metamorphic structures that are probably pre- or contemporaneous Pan African deformation event that led to the widespread emplacement of granodioritic and granitic injections in rocks of the basement while the NNW-SSE, NNE-SSW and E-W brittle structures in- 
filled by pegmatite dykes and quartz veins are probably close or end of Pan-African.

Migmatization is believed to be the first thermo-tectonic event and resulted in plastic deformation $\mathrm{D}_{1}$ and regional $\mathrm{S}_{1}$ foliation, defined by tight isoclinal fold, compositional banding and $\mathrm{N}-\mathrm{S}$ preferred orientation of mafic minerals. The $\mathrm{D}_{2}$ deformation which is co-axial with $\mathrm{D}_{1}$ resulted in the formation of decimeter size $\mathrm{F}_{2}$ isoclinal folds, $B_{2}$ boudins and eye ball structures that are parallel to $S_{1}$ plane schistocity. Granitic leucosome injection into the dioritic and granodioritic migmatite gneiss revealed strike-slip faults with dextral sense of movements. $\mathrm{D}_{3}$ deformation, commonly found in the Kushaka Gneiss Complex, south of Kalangai transcurrent fault is a phase of superimposed folding, where $\mathrm{F}_{3}$ structures transpose and re-orientate the $\mathrm{F}_{2}$ structures. Extrusion of tholeiitic basalt and granitization in the Kushaka Complex with near circular deep fractures south of the Kalangai fault and characterized by fragmented proto-mylonitic staurolite, resulted in brittle deformation and open fold $\left(\mathrm{F}_{3}\right)$. The $\mathrm{D}_{4}$ deformation resulted in N-S, NE-SW and E-W fractures and joints which serve as channels for epigenetic gold-sulphide and rare metal mineralization reported in the study area.

\section{ACKNOWLEDGEMENT}

The authors acknowledge the assistance of Mr Adekunle Omokanye as a guide during the field mapping exercise. We are indebted to the staff of Geochronology Laboratory for their efforts in carrying out whole rock major and trace elements analysis. Insights and contributions of Prof. Abba and Prof. Ajibade in the course of this work are greatly acknowledged. The contributions and encouragement of Prof. Najime Tavershima, Head, Geology Department and Dr S. S. Magaji is also acknowledged. Appreciation goes to Mr. A.K. Amuda and Mr E. B. Animashaun of the Department of Geology, Ahmadu Bello University Zaria for thin section preparation and sample pulverization respectively. The help of Peter Nagl, University of Vienna, with the whole rock geochemical analysis is also acknowledged.

\section{REFERENCES}

Abubakar, Y. I. (2012). An Integrated Technique in Delineating Structures: A Case Study of the Kushaka Schist Belt Northwestern Nigeria. International Journal of Applied Science and Technology Vol. 2 No. 5

Ananaba, S.E., Ajakaye, D.E., (1987). Evidence of tectonic control of mineralization in Nigeria from lineament density analysis. A Landsat study. International Journal of Remote Sensing 10, 1445-1452.

Ajibade, A.C., Woakes, M. and Rahaman, M.A. (1984). Proterozoic crustal development in the Pan-African regime of Nigeria. In: Proterozoic lithospheric evolution, Kroner, A. (ed). American Geophysical Union, Washington DC. USA. 259-271.

Ajibade, A.C., Woakes, M. and Rahaman, M.A, (1987). Proterozoic crustal development in the Pan-African regime of Nigeria, In: Proterozoic lithospheric evolution. America Geophysical Union. Spectrum Publishing, (Edited by Kroner, A.), 259-271.

Ajibade A. C., Anyanwu, N. P. C., Okoro, A. U. and Nwajide, C. S. (2008). The Geology of Minna area. Nigeria Geological Survey Agency Bulletin No 43.

Danbatta, U.A., (2008a). Precambrian crustal development in the north western part of Zuru schist belt, northwestern Nigeria. Journal of Mining Geology. 44(1) 45-56.

Danbatta, U.A. (2008b). A review of the evolution and tectonic framework of the schist belts of Western Nigeria, West Africa. African Geoscience Review 15, 2, 145-158.

Ekwueme, B.N., (1985). Petrology, geochemistry and Rb-Sr. geochronology of metamorphosed rocks of Uwet area. SE Nigeria. Unpubl Ph.D Thesis; Univ. of Nig. Nsukka.

Ekwueme, B.N., (2003). The Precambrian Geology and evolution of the southeastern Nigerian Basement Complex. Univ. of Calabar press.

Ekwueme, B.N and Ephraim, B E., (2005). Rare Earth Element Geochemistry and Protoliths of Schists in Southeast Lokoja, Central Nig. Global Journal of Geological Sciences, 3, (1): 9-15.

Ferre, E.C, Deleris, J, Bouchez, J.L, Lar, A.U., and Peucat, J.J (1996): The Pan-African Reactivation of Eburnean and Archaen Provinces in Nigeria: Structural and Isotopic Data. In: Journal of the Geological Society, London, 153: pp. 719-728.

Fitches, W.R., Ajibade, A.C., Egbuniwe, I.G., Holt. R.W. and White, J.B. (1985). Late Proterozoic schist belts and plutonism in NW Nigeria. Journal of Geological Society, London 142, 319-337.

Goki, N.G., Dada, S.S., Oha, A.I and Moumouni, A., (2010). An Interpretation of tectonic Elements of the Kanke Basement, Central Nig. Medwell online journal of Earth Sciences, 4, (2): 89-94.

Garba, I. (2000). Origin of Pan-African mesothermal gold mineralization at Bin Yauri, Nigeria. Journal of African Earth Sciences, 31, 2, 433-449.

Garba, I. (2002). Late Pan-African tectonics and origin of Gold mineralization and Rare-metal pegmatites in the Kushaka schist belt, northwestern Nigeria. Journal of Mining and Geology. 38, 1, 1-12.

Grant, N.K. (1978). Structural distinction between metasedimentary cover and an underlying basement in the 600 m.y. old Pan-African domain of Northwestern Nigeria, West African. Geological Society America Bulletin 
89, 50-58.

Kolawole, M.S., Martins Onimisi, M. and Olobaniyi, S.B. (2017). Field Occurrence and Structural Characteristics of Basement Rocks around Kabba-Bunu area in Part of Kabba-Lokoja-Igarra Schist Belt, Southwestern Nigeria. Global Journal of Pure and Applied Sciences Vol. 23, 2017: 263-274

McCurry, P. (1976). The geology of the Precambrian to Lower Palaeozoic of northern Nigeria- a review. In: Geology of Nigeria. C.A. Kogbe (Ed). Elizabethan Publishing Company. Lagos, 15-39.

Okunlola, O. A., (2008). Deformation and Mineralization in the Basement of Nigeria; AFR-03 Geology of Africa development strategies for mining sectors of African countries, proceedings paper at Int. Geological Congress-Oslo.

Okunlola, O. A., and Okoroafor, R. E. (2009). Geochemical and petrogenetic features of schistose rocks of the Okemesi fold belt, Southwestern Nigeria. RMZ - Materials and Geoenvironment, Vol. 56, No. 2, pp. 148162,2009

Olarewaju, V.O. (1988), Petrology and Geochemistry of the charnockitic and granitic rocks of Ado Ekiti - Akure, SW Nigeria, In: Oluyide, P. O. (eds). Precambrian Geology of Nigeria, Geol. Surv. Nigeria publ., pp. 129143.

Onyeagocha, A.C. and Ekwueme, B.N. (1990). Temperature-pressure distribution patterns in metamorphosed rocks of the Nigerian Basement Complex - a preliminary analysis. Journal of African Earth Sciences 11, 8393.

Oyinloye, A.O. and Ojo, A.O. (1988). Physical and Mineral Evaluation of clay Deposits at Ado-Ekiti. Journal of Techno-Science, (2) 1, 49-52.

Rahaman, M. A. (1976). Review of the basement geology of southwestern Nigeria. In: Geology of Nigeria. (Edited by C. A. Kogbe). Elizabethan Publishing Company Lagos, 41-58

Rahaman, M. A. 1988. Recent advances in the study of the basement complex of Nigeria. In: Precambrian Geology of Nigeria. (Eds. Oluyide et al.) a publication of the Geol. Surv. Nigeria. 71-43.

Russ, W. (1957). The geology of parts of Niger, Zaria and Sokoto provinces with reference to the occurrence of gold. Geological Survey Nigeria Bulletin 29.

Truswell, J.F. and Cope, R.N. (1963). The geology of parts of Niger and Zaria Provinces, Northern Nigeria. Bulletin Geological Survey Nigerian 29, 38.

Tubosun, I.A., Lancelot, J.R., Rahaman, M.A., Ocan, O., (1984). U-Pb Pan-African ages of two charnockitegranite association from southwestern Nigeria. Contribution to Mineralogy and Petrology 88, 188-195.

Turner, D.C. (1983): Upper Proterozoic schist belts in the Nigerian sector of the Pan African Province of West Africa. Precambrian Research 21, 5-79.

Woakes. M.. Rahaman, M.A. \& Ajibade. A.C. (1987). Some metallogenic features of the Nigerian basement. Journal of African Earth Sciences, 6, 655-664. 


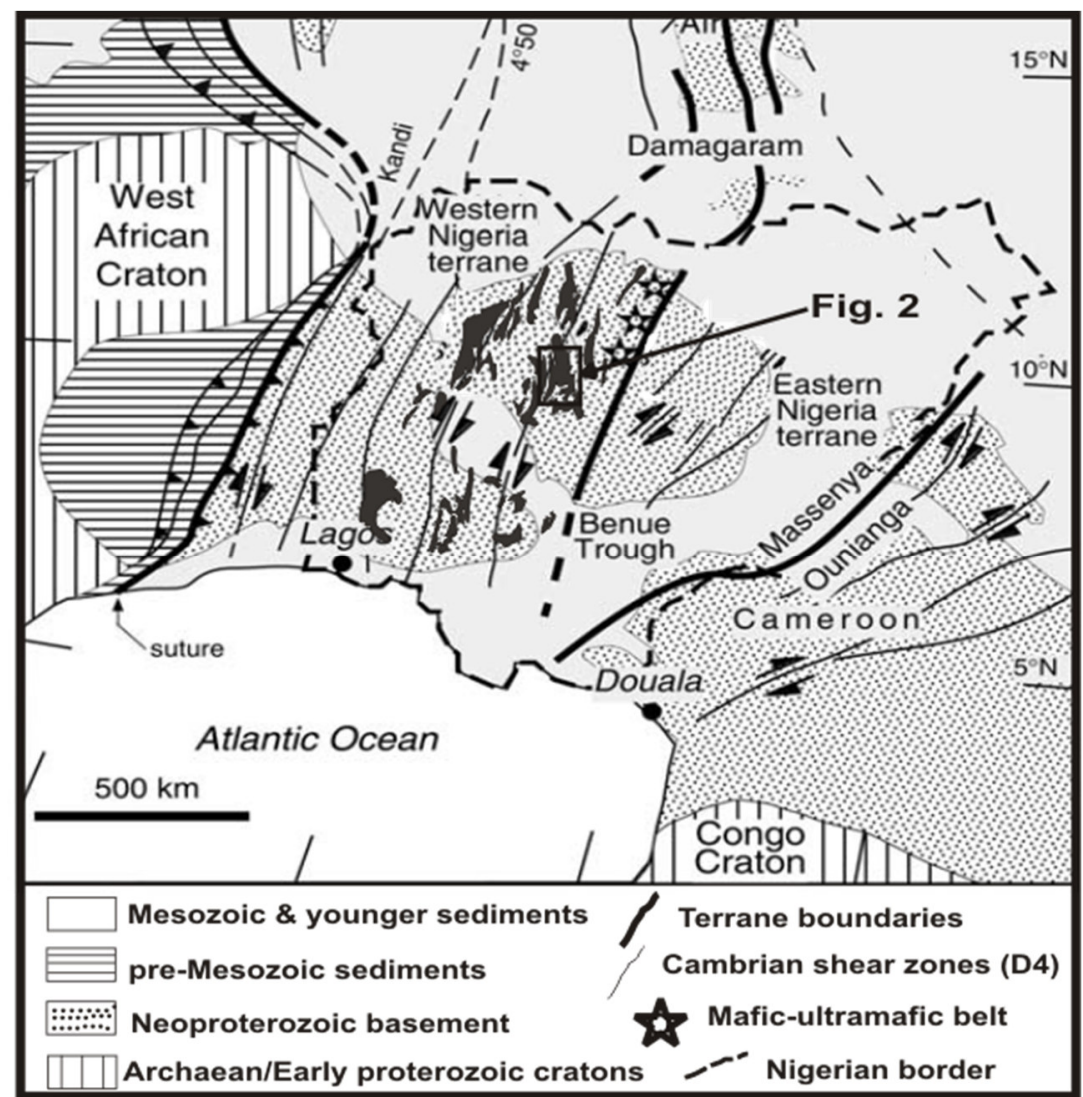

Fig. 1: Geological sketch map of the Nigeria province showing the Neoproterozoic terrane amalgamation between the cratons of West Africa and Congo. Modified after Ferre et al. (1996) 


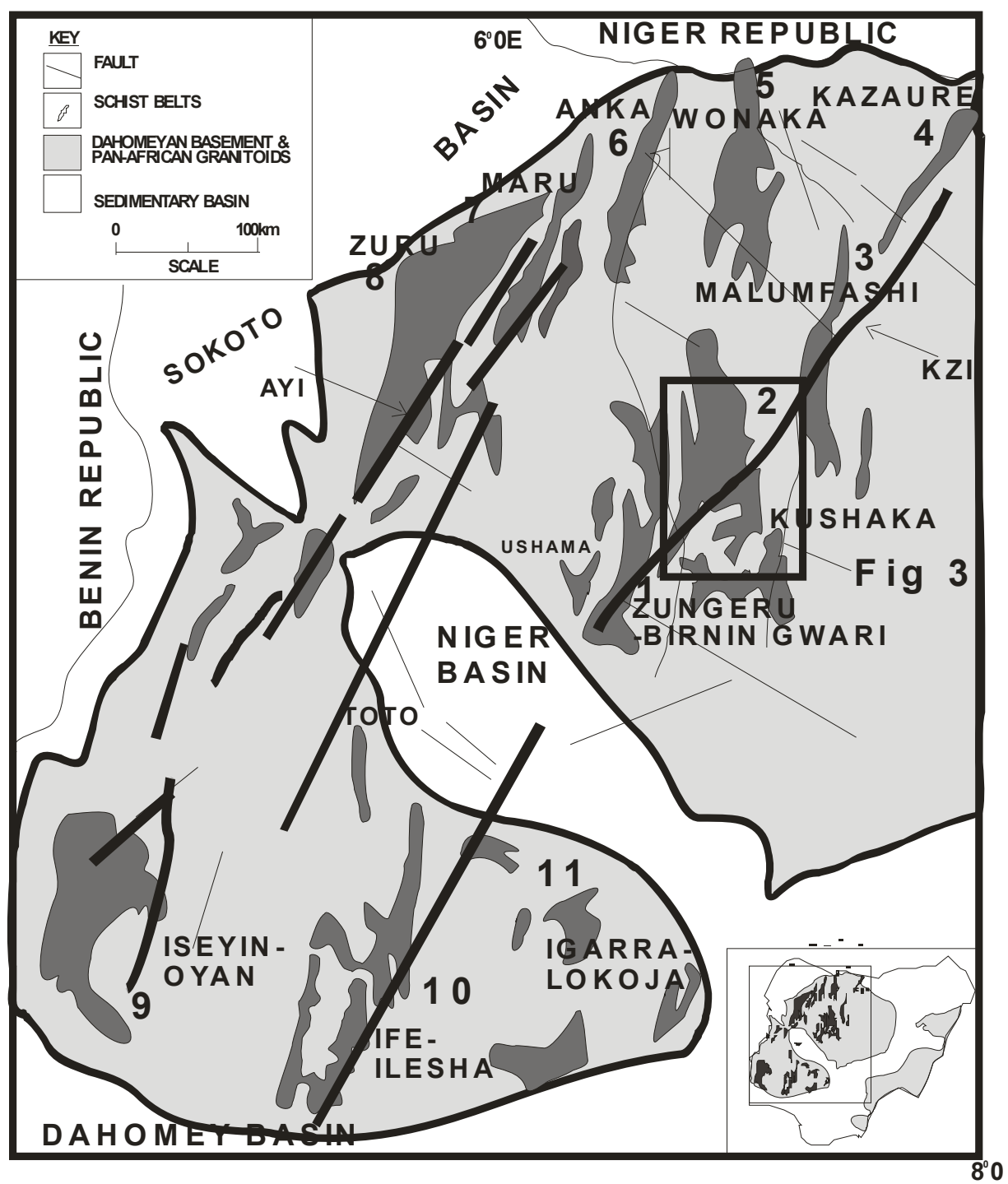

Fig. 2: Simplified geological map of western half of Nigeria showing the distribution of the schist belts and major faults. Anka-Yauri-Iseyin Fault (AYI). Kalangai-Zungeru-Ifewara Fault (KZI) (modified after NGSA, 1994). 


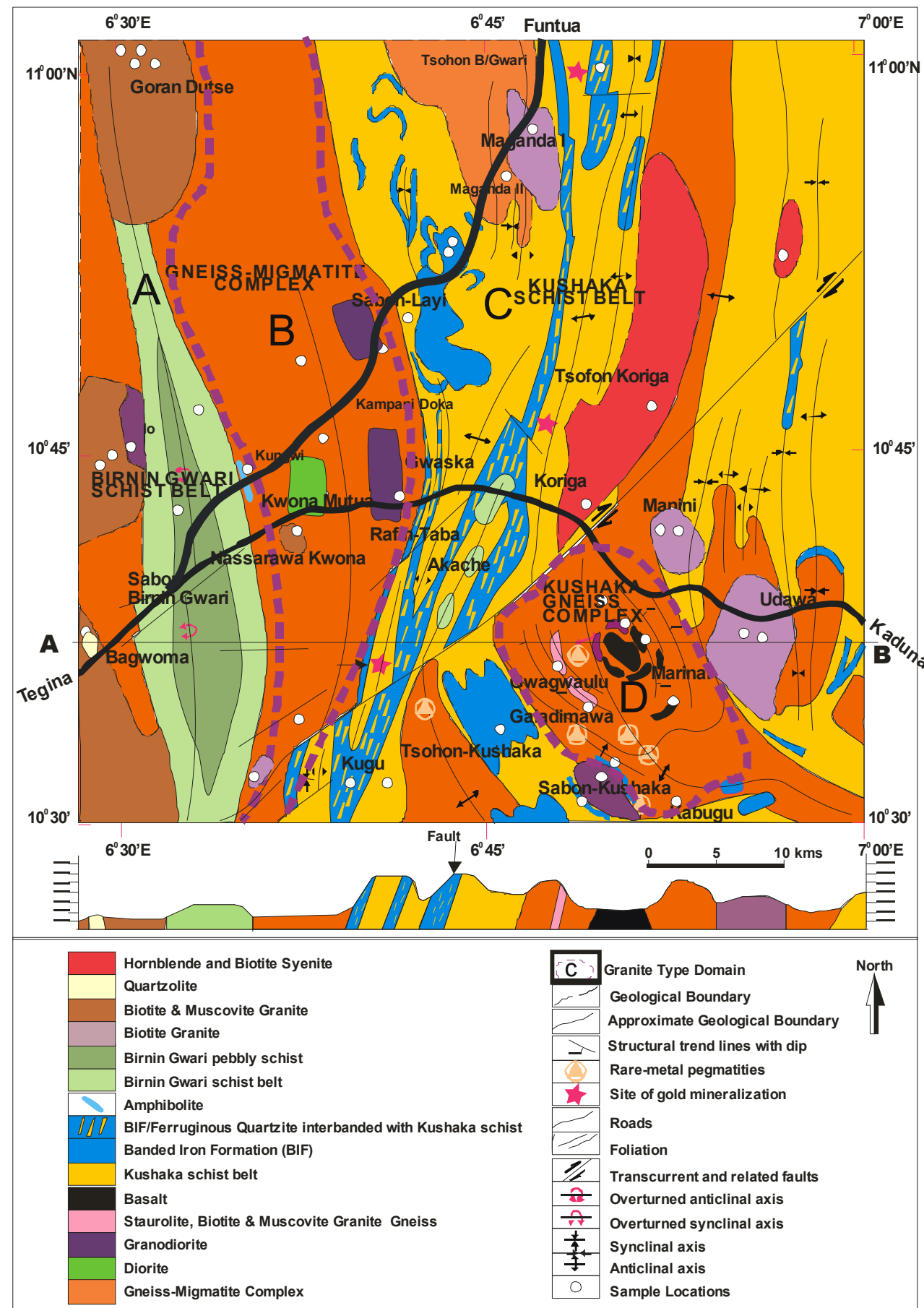

Fig. 3: Geological map of Kushaka (Sheet 122) Modified after Truswell and Cope, (1963). 

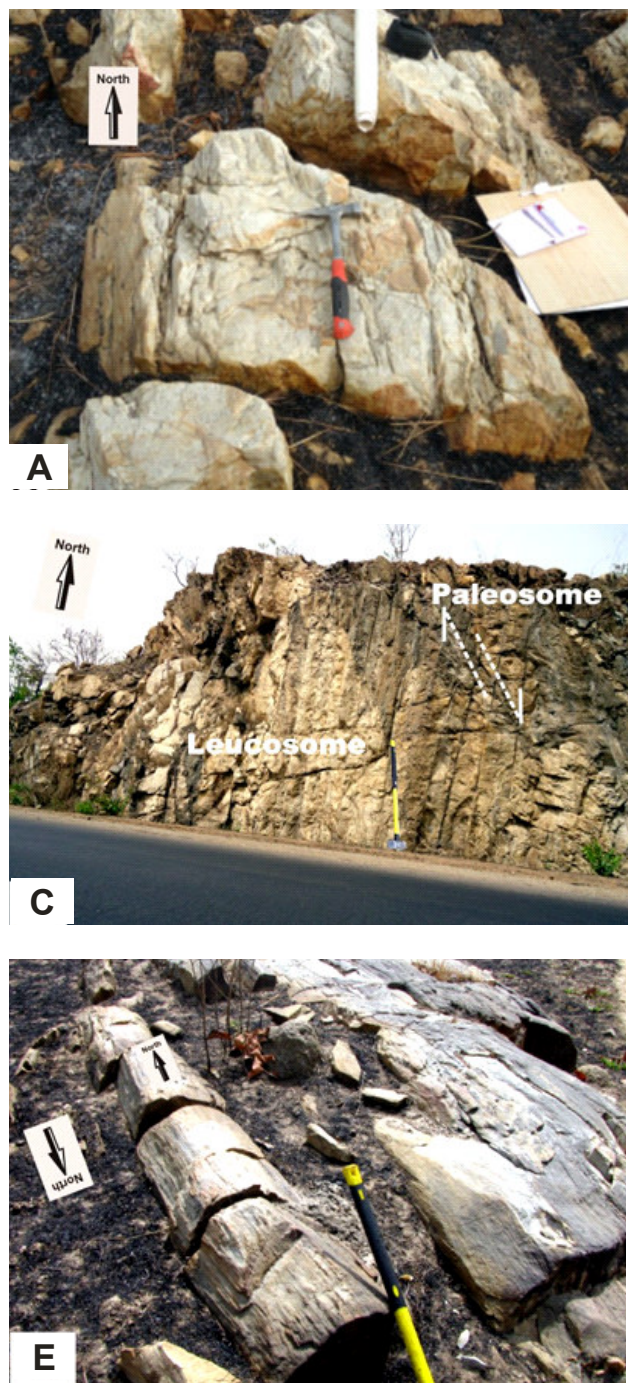
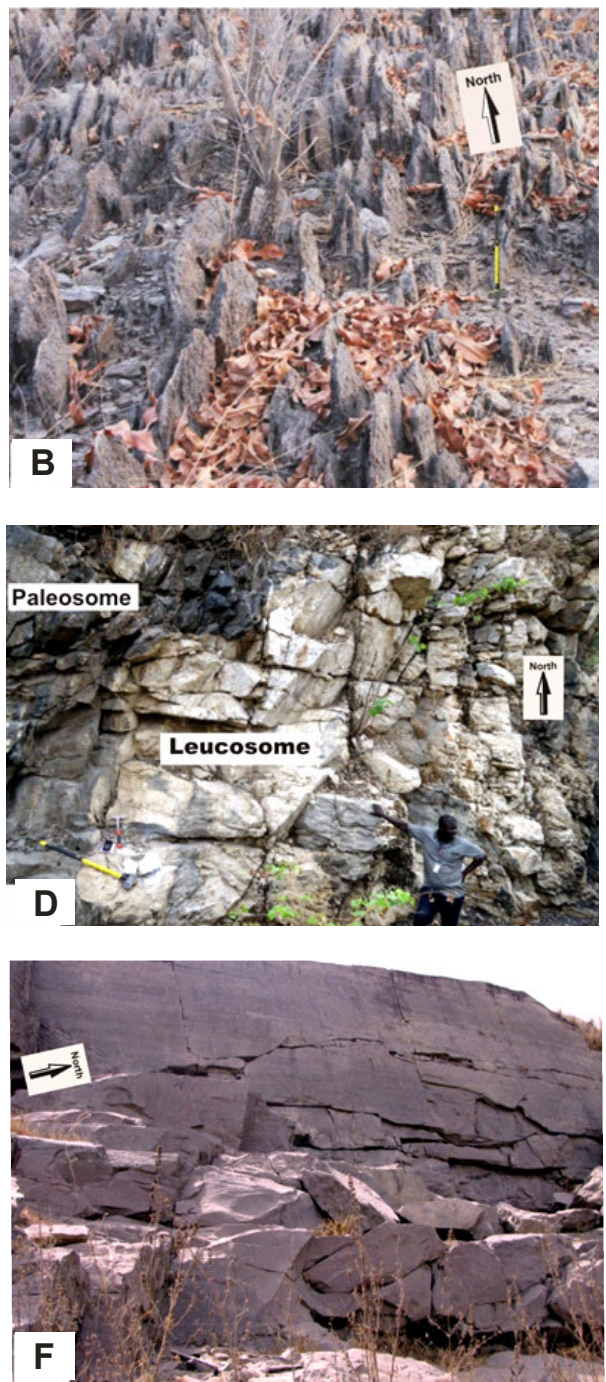

Fig. 4: Field photograph of (A): Fissile quartzite dyke in Nasarawa Kwona (N10 $0^{0} 41^{\prime} 13^{\prime \prime}$ E $6^{0} 35^{\prime}$ 42") and (B): Ferruginous quartzite outcrop in Maganda with vertical dips and well defined schistocity (N10 $58^{\prime} 18^{\prime \prime}$ " E $6^{\circ} 47^{\prime}$ 43”). (C): paleosome and leucosome outcrop along road cuttings in Kwona Mutua (N10 41' 56" E 6 39' 50") with dextral movement and discordant porphyritic; (D): granitic leucosome injection with E-W foliation and

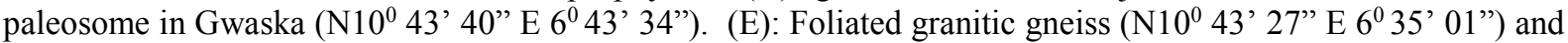
$(\mathrm{F})$ : granitic gneiss outcrop used as quarry $\left(\mathrm{N}_{10} 0^{\circ} 45^{\prime} 10^{\prime \prime}\right.$ E $\left.6^{0} 36^{\prime} 13^{\prime \prime}\right)$ in Kampani Doka. 

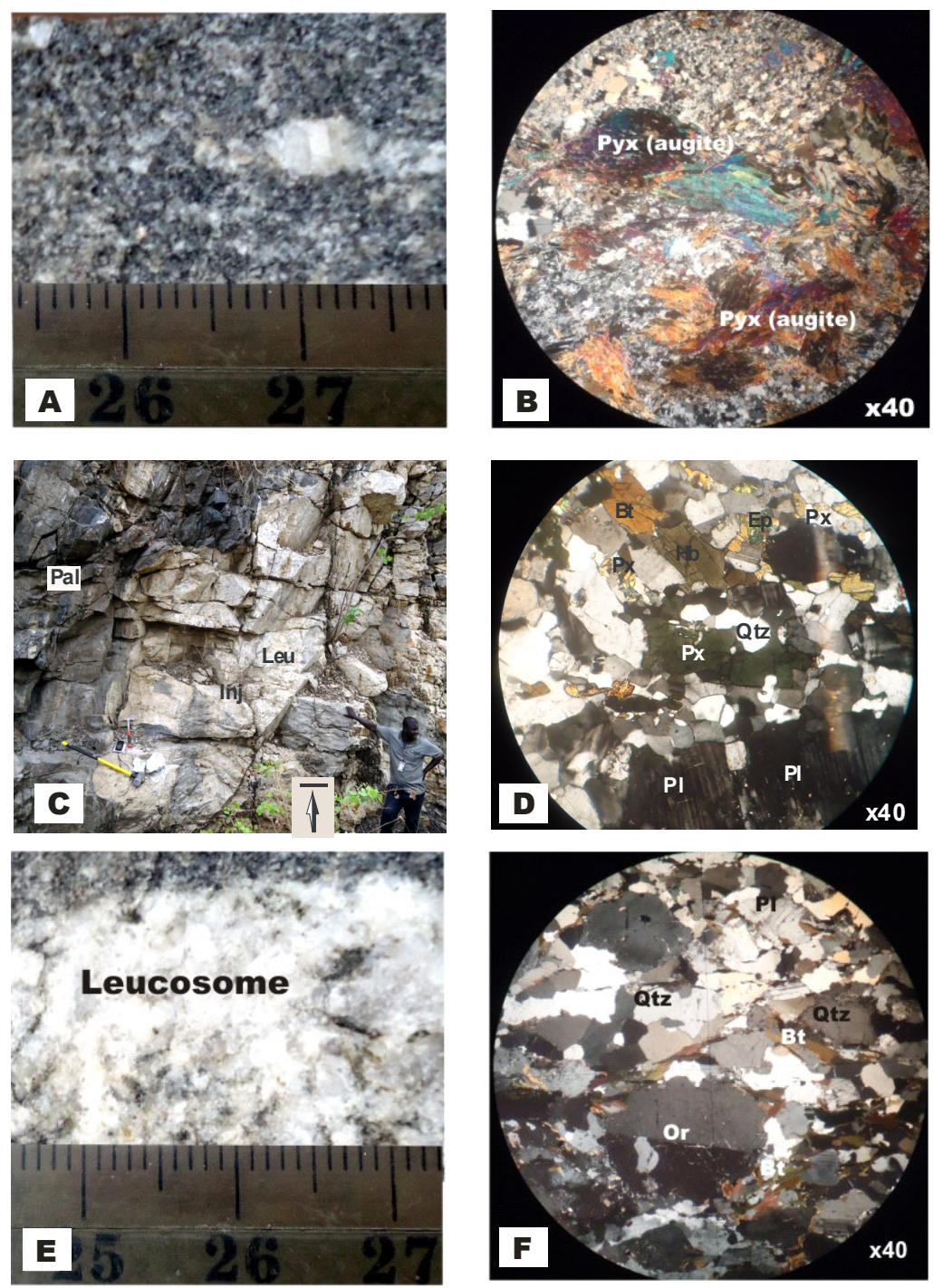

Fig. 5: Hand specimen and photomicrograph of AB: Dioritic rock (paleosome) in Ungwan Madaki and CD: Granodioritic (paleosome) in Gwaska and EF: leucosome: in Gwaska 

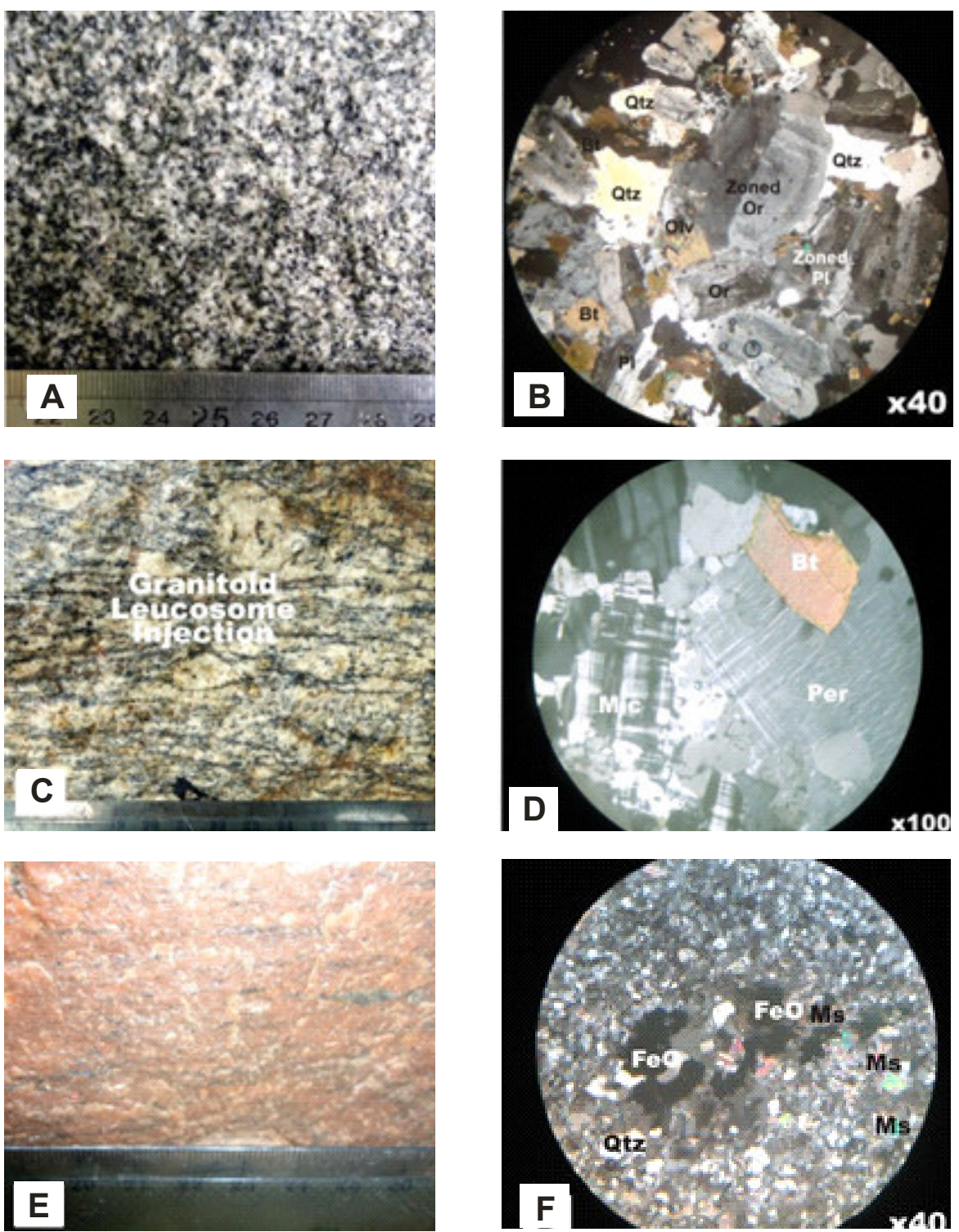

Fig. 6: Hand specimen and photomicrograph of $(\mathrm{AB})$ : Tonalite around Sabo-Layi in the migmatite gneiss; $(\mathrm{CD})$ : Granitoid (leucosome) injection in Gwaska and (EF): Kampani Doka biotite and muscovite granitoid gneiss. 

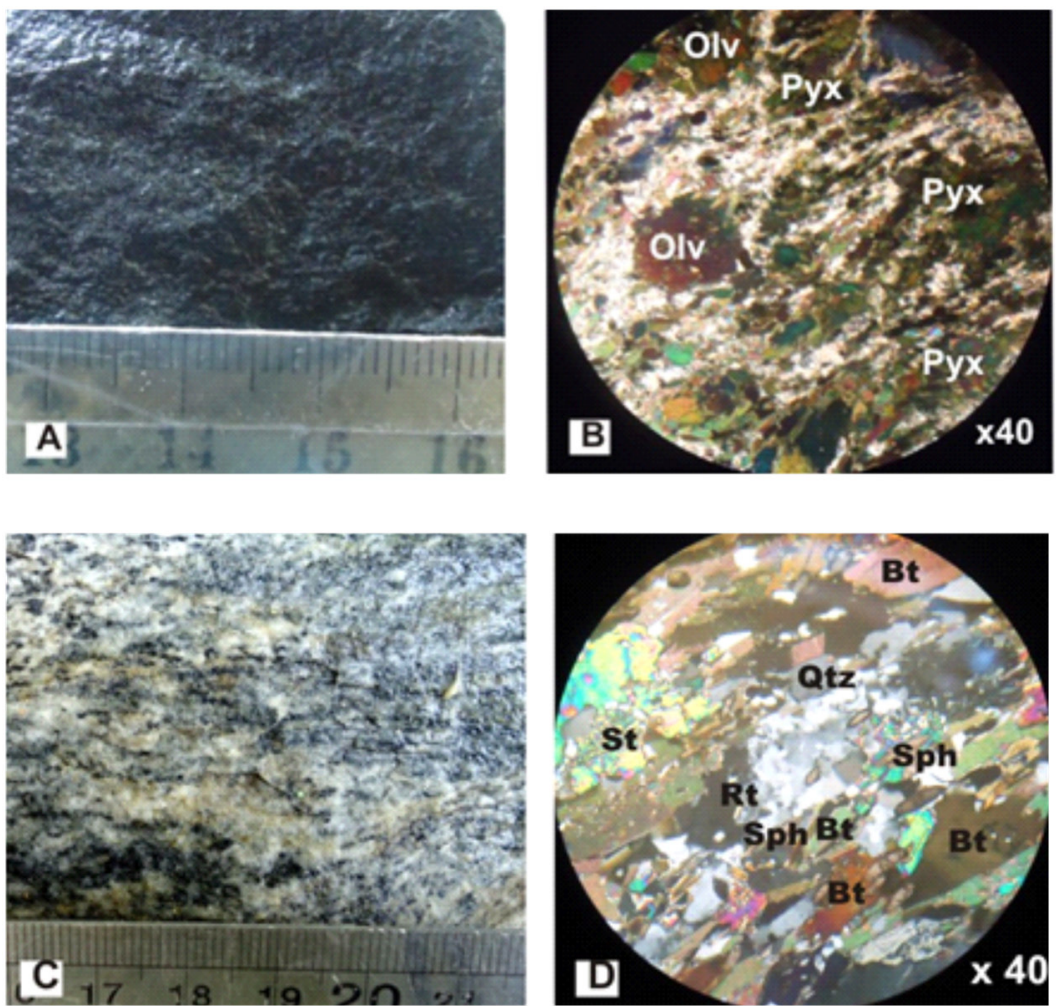

Fig. 7: Hand Specimen and Photomicrograph of $(\mathrm{AB})$ basalt and $(\mathrm{CD})$ staurolite and biotite gneiss in the Kushaka Gneiss Complex
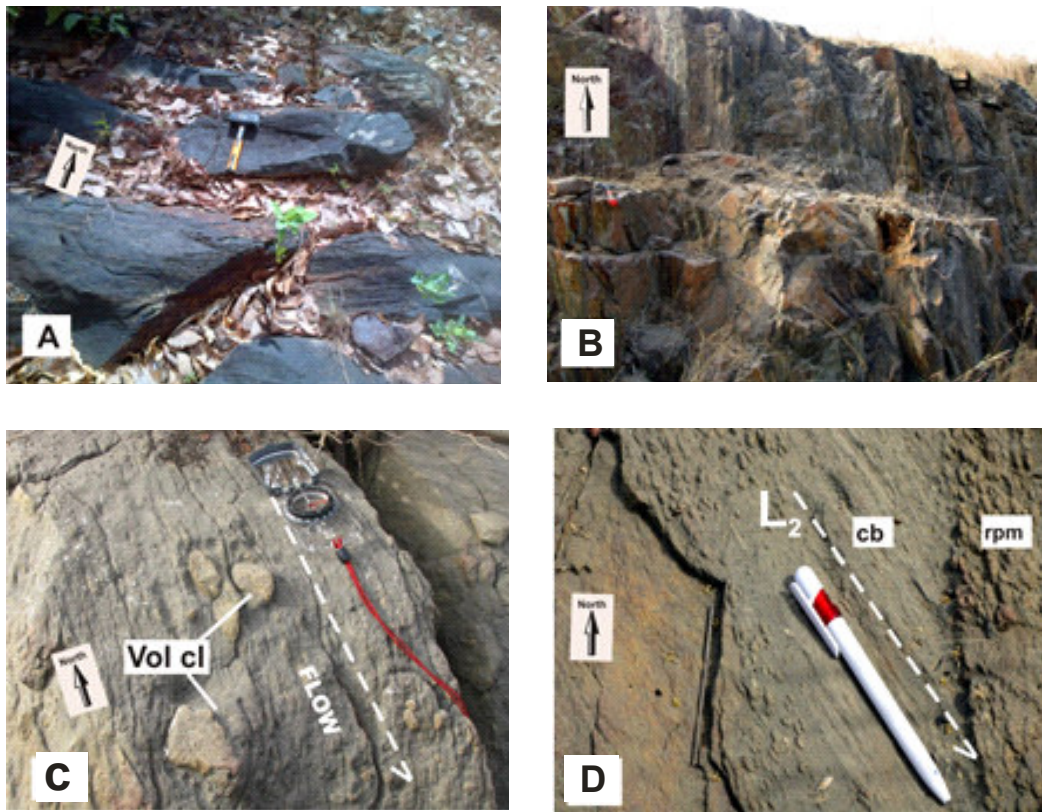

Fig. 8: Field occurrence of (A): Basalt in Kushaka Gneiss Complex (N10 33' 27" E 60 51' 31") and (B): Greyish Sabo-Layi schist (N10 49' 38" E 6 42'02") in Kushaka Schist Belt and (C and D): Birnin Gwari staurolite, biotite, iron-rich and quartz schist (N10 42 ' 48" E 6033' 42”). 

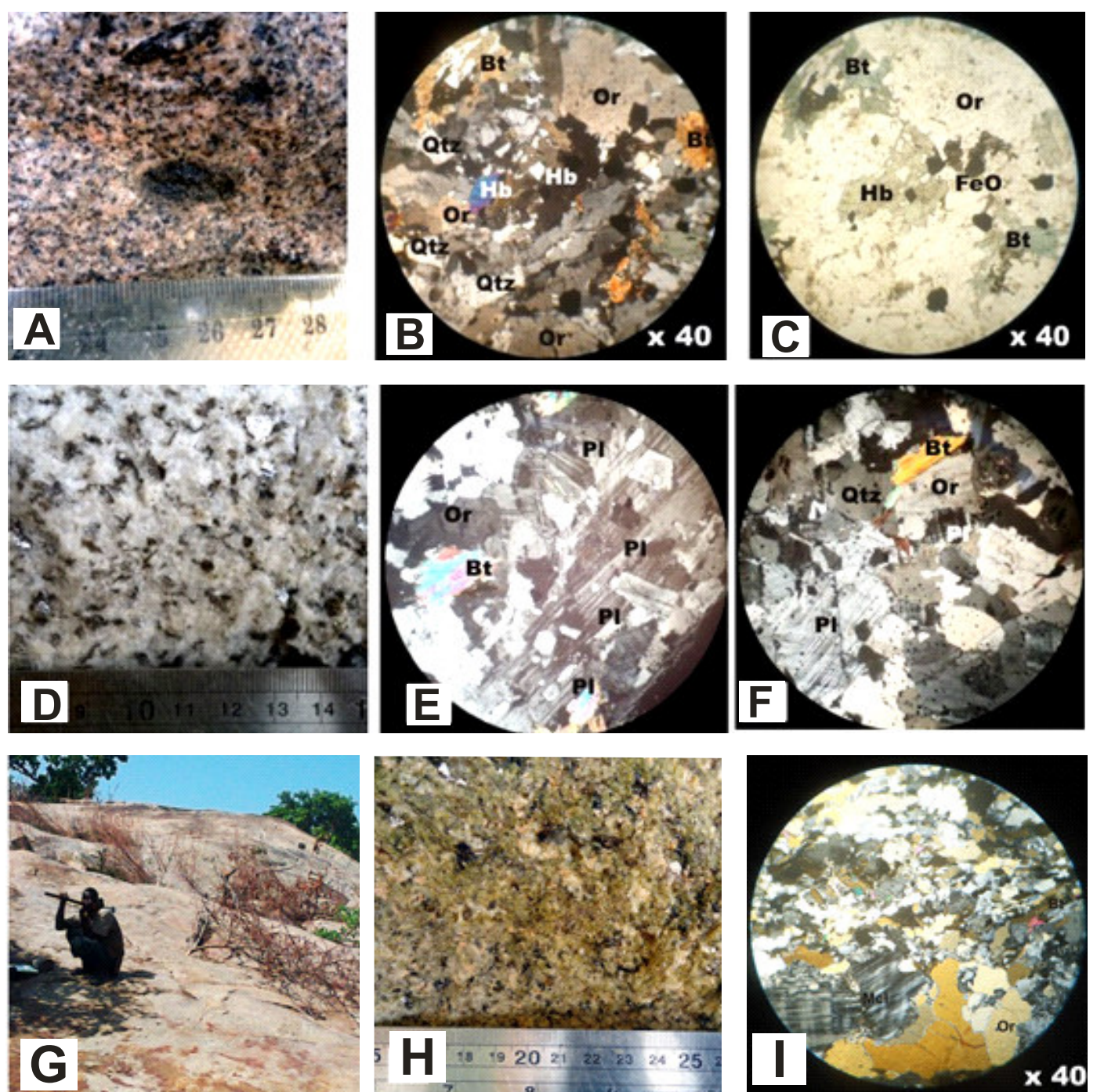

Fig. 9: Hand Specimen and Photomicrograph of $(\mathrm{ABC})$ biotite hornblende syenite; $(\mathrm{CDE})$ porphyritic biotite granite in Kushaka schist belt and (GHI) outcrop, hand specimen and photomicrograph of porphyritic biotite granite in Birnin Gwari schist belt. 


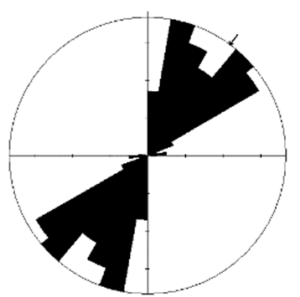

A (1-90)

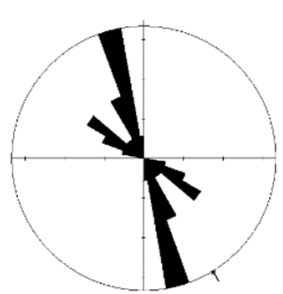

B (90-180)

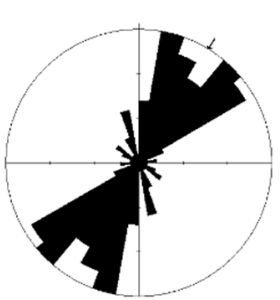

C (1-180)

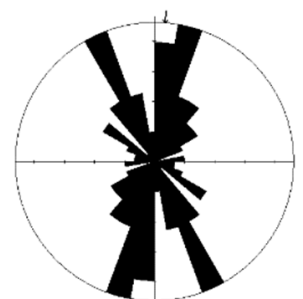

$\mathrm{D}$

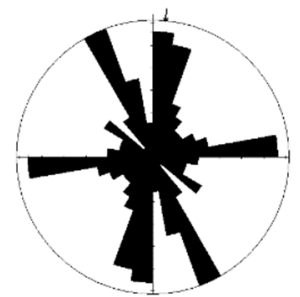

$\mathrm{E}$

Fig. 10: Rose plot of (A, B and C): foliations and mineral lineations in Basement rocks; D): Joints and fractures in the basement rocks; E): Joints and fractures in the Kushaka and Birnin Gwari granite in the study area.

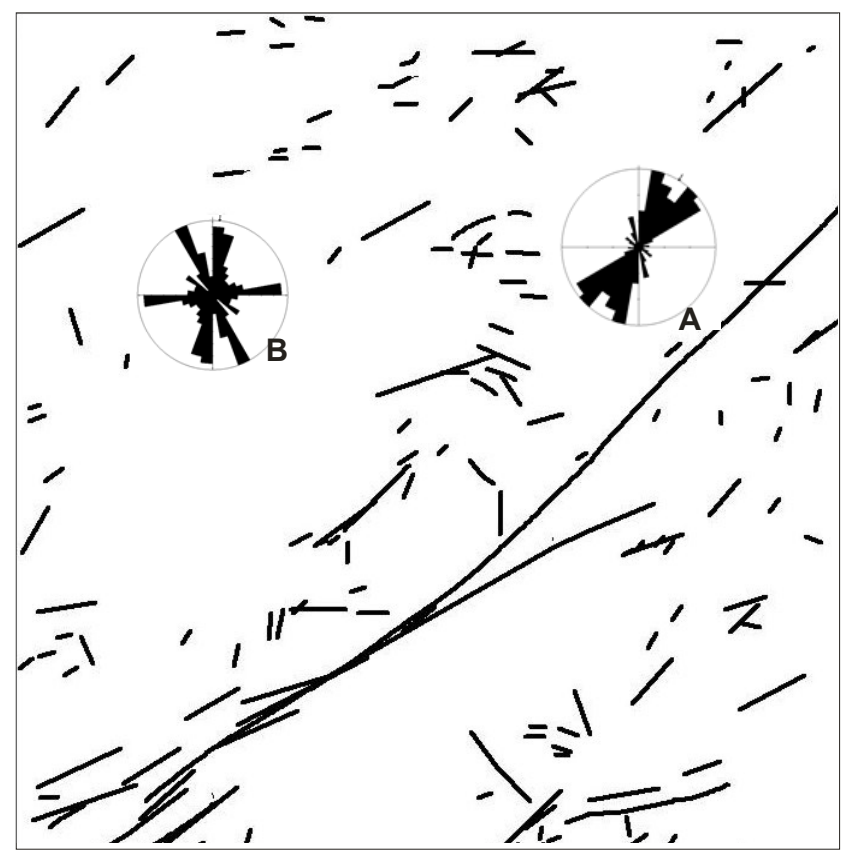

Fig. 11: Composite lineament Aeromagnetic, Landsat and DEM map of the study area (after Abubakar, 2012). A and B are field measurements for ductile (foliation) and brittle (fractures and joints) structures respectively. 

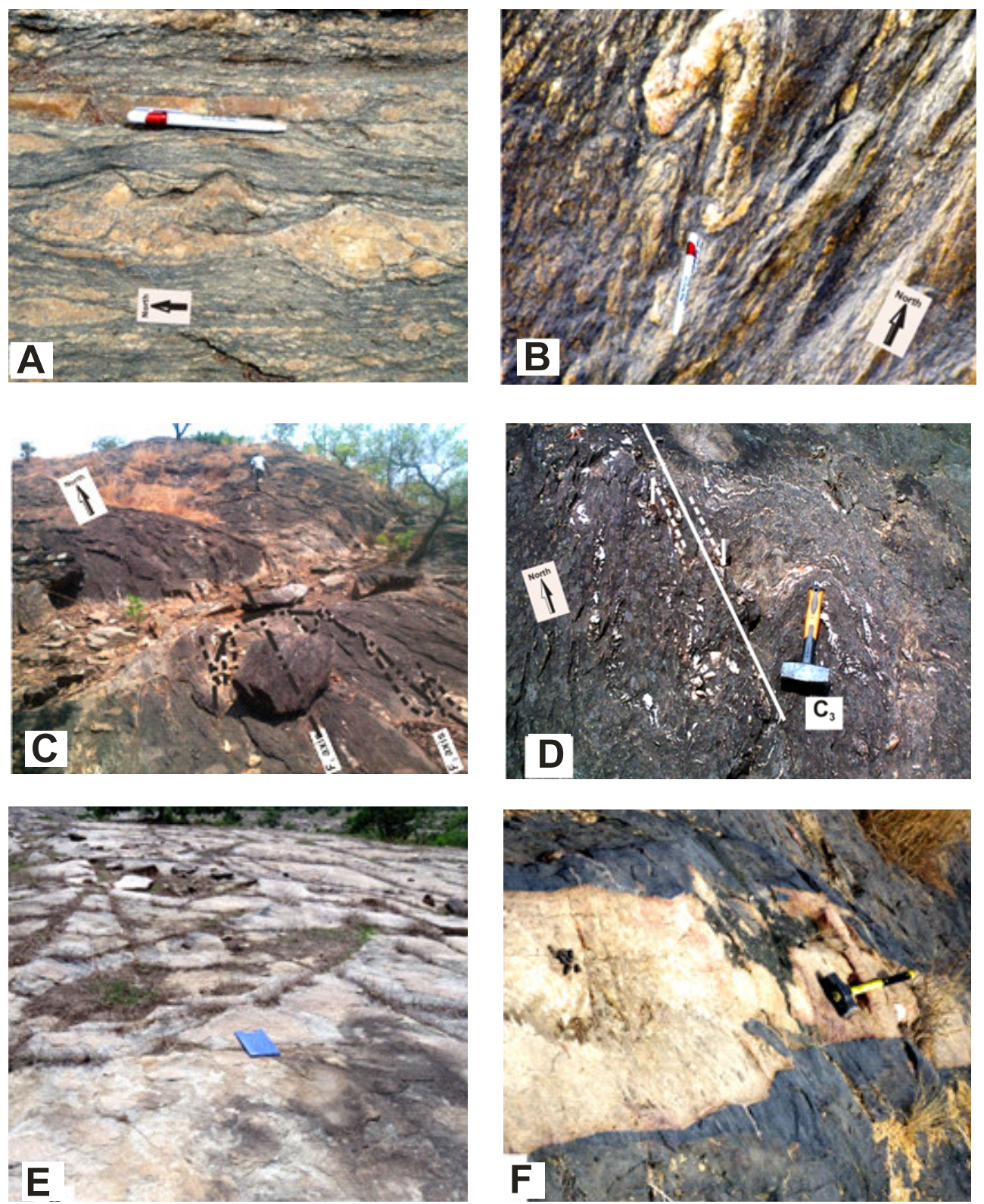

Fig. 12: Structural patterns in the rocks of the study area. (A) Asymetrical boudinage, eye ball structure and (B): $\mathrm{F}_{2}$ isoclinal folds with $\mathrm{S}_{1}$ schistocity parallel to the axial plane of the fold, with crestal thickening in the migmatite gneiss (N10 $0^{\circ}$ ' $87^{\prime \prime}$ E $\left.6^{0} 38^{\prime} 49^{\prime \prime}\right)$; (CD): $\mathrm{F}_{3}$ open transposing $\mathrm{F}_{2}$ isoclinal fold with dextral movement in Kushaka Gneiss Complex (N10 $0^{\circ} 34^{\prime} 50^{\prime \prime}$ E $\left.6^{0} 52^{\prime} 38^{\prime \prime}\right)$; (EF): Joints and fractures in the granite and granitic dyke intrusion in Birnin Gwari schist. 
Table 1: Average Modal Composition of Migmatite Gniess (Paleosome and Leucosome), granitic Gneiss and granitoids in the study area

\begin{tabular}{|c|c|c|c|c|c|c|c|}
\hline \multirow[t]{2}{*}{ Mineral } & \multicolumn{2}{|c|}{ Migmatitic Gneisses } & \multirow[t]{2}{*}{ Tonalite } & \multirow{2}{*}{$\begin{array}{l}\text { Granite } \\
\text { Gneiss }\end{array}$} & \multirow{2}{*}{$\begin{array}{l}\text { Kushaka } \\
\text { Granite }\end{array}$} & \multirow{2}{*}{$\begin{array}{l}\text { Kushaka } \\
\text { Syenite }\end{array}$} & \multirow{2}{*}{$\begin{array}{l}\text { B/ Gwari } \\
\text { Granite }\end{array}$} \\
\hline & Paleosome & Leucosome & & & & & \\
\hline Quartz & 20 & 30 & 20 & 30 & 20 & 20 & 30 \\
\hline Plagioclase & 10 & 10 & 60 & & 5 & 5 & 5 \\
\hline K-feldspar & & 40 & 5 & 25 & 35 & 35 & 45 \\
\hline Hornblende & 10 & & & & 20 & 20 & \\
\hline Biotite & 5 & 10 & 10 & 5 & 10 & 10 & 10 \\
\hline Muscovite & & & & 25 & & & 5 \\
\hline Pyroxene & 45 & & 5 & & & & \\
\hline Epidote & 5 & & & & & & \\
\hline Iron-oxide & 5 & 5 & & 10 & 5 & 5 & \\
\hline Accessory & & 5 & & 5 & 5 & 5 & 5 \\
\hline Total & 100 & 100 & 100 & 100 & 100 & 100 & 100 \\
\hline
\end{tabular}

Table 2: Summary of strike azimuth frequency data of structures (foliations and joints / fractures) in the study area

\begin{tabular}{|c|c|c|c|c|c|c|c|c|}
\hline \multirow{3}{*}{$\begin{array}{l}\text { Structural } \\
\text { Elements } \\
\text { Azimuth } \\
\text { (Degree) }\end{array}$} & \multirow{2}{*}{\multicolumn{2}{|c|}{$\begin{array}{c}\text { DUCTILE } \\
\text { Foliations }\end{array}$}} & \multicolumn{6}{|c|}{ BRITTLE } \\
\hline & & & \multicolumn{2}{|c|}{$\begin{array}{l}\text { Joints and } \\
\text { Fractures }\end{array}$} & \multicolumn{2}{|c|}{$\begin{array}{l}\text { Joints and } \\
\text { Fractures in } \\
\text { (Granitoids) }\end{array}$} & \multicolumn{2}{|c|}{$\begin{array}{c}\text { Total Brittle } \\
\text { Structures }\end{array}$} \\
\hline & & $\begin{array}{l}\% \\
\text { Frequency }\end{array}$ & No & $\begin{array}{c}\% \\
\text { Frequency }\end{array}$ & & $\begin{array}{l}\% \\
\text { Frequency }\end{array}$ & No & $\begin{array}{l}\% \\
\text { Frequency }\end{array}$ \\
\hline N0-30 & 35 & 35 & 32 & 32 & 26 & 26 & 58 & 29 \\
\hline N31-60 E & 40 & 40 & 18 & 18 & 10 & 10 & 28 & 14 \\
\hline $61-90(E-W)$ & 6 & 6 & 5 & 5 & 20 & 20 & 25 & 12.5 \\
\hline $91-120$ & 3 & 3 & 5 & 5 & 11 & 11 & 16 & 8 \\
\hline $121-150$ & 6 & 6 & 15 & 15 & 10 & 10 & 25 & 12.5 \\
\hline $331-360(\mathrm{~N} 0-31 \mathrm{~W})$ & 10 & 10 & 25 & 25 & 23 & 23 & 48 & 24 \\
\hline Total & 100 & 100 & 100 & 100 & 100 & 100 & 200 & 100 \\
\hline
\end{tabular}

